\title{
Characterization of cellulose and sugarcane (Saccharum spp.) straw from five cultivars grown in the humid tropic of Mexico
}

\author{
Liliana Yanet López-Velázquez ${ }^{1}$; Sergio Salgado-García ${ }^{1}$; Samuel Córdova-Sánchez ${ }^{2 *}$; \\ Cintya Valerio-Cárdenas ${ }^{2}$; Gloria Ivette Bolio-López ${ }^{2}$; Raúl Castañeda-Ceja ${ }^{3}$; \\ Luz del Garmen Lagunés-Espinoza ${ }^{1}$; Richart Falconi-Calderón ${ }^{3}$ \\ 1 MASCAÑA Research Group. Colegio de Postgraduados. Tabasco campus. Km 3.5 Per. Carlos A. Molina \\ s/n 86500 H. Cárdenas-Tabasco, Mexico. \\ 2 UPGH-Universidad Popular de la Chontalpa. Road to Cárdenas-Huimanguillo, Km. 2.0, R/a. Paso and \\ Cárdenas, Tabasco, México. \\ 3 Universidad Juárez Autónoma de Tabasco, Mexico. \\ * Correspondence: sacorsa_1976@hotmail.com
}

Gitation: López-Velázquez, L. Y., Salgado-García, S., Córdova-Sánchez, S., Valerio-Cárdena., C., Bolio-López, G.I., Castañeda-Ceja, R., LagunésEspinoza, L. del C., \& FalconiCalderón, R., (2021). Characterization of cellulose and sugarcane (Saccharum spp.) straw from five cultivars grown in the humid tropic of Mexico. Agro Productividad. https://doi.org/10.32854/ agrop.v14i9.2034

Editor in Chief: Dr. Jorge Cadena Iñiguez

Received: May 17, 2021. Accepted: September 3, 2021. Published on-line: October 12, 2021

This work is licensed under a Creative Commons Attribution-NonCommercial 4.0 International license. \section{(1) (\$)}

\section{ABSTRACT}

Objective: The aim of this study was to determine the cellulose content and characteristics of sugarcane straw from the cultivars MEX 69-290, MEX 68-P-23, CO-997, SP 70-1284 and CP 72-2086.

Design/methodology/approach: A completely random experimental design with six replicates was conducted; the study factor was the sugarcane straw from the five evaluated cultivars. For cellulose extraction, the sodium hydroxide (soda) method was used on dried sugarcane straw of $2 \mathrm{~mm}$. The crystallinity and crystal size were determined with x-ray diffraction (XRD); the fiber length had achieved a measurement with a DMRE optical microscope.

Results: Among the results, it can be noted that the cultivars MEX 69-290 and SP 70-1284, which presented less cellulose content ( $8.4 \mathrm{~g}$ and $8.5 \mathrm{~g}$ ) and lower yields (42.1\% and 42.6\%), while the cultivar CO-997, presented higher cellulose content and yield which ranged from $9.8 \mathrm{~g}$ to $49.8 \%$. The crystallinity of cellulose was higher in the sugarcane straw from the cultivars SP 70-1284 and MEX 68-P23. The crystal size of cellulose was 2.3 $\mathrm{nm}$. The length of cellulose fibers was small $(<945.7 \mu \mathrm{m})$.

Study limitations/implications: The collection of samples in the field, as well as selected materials for digestion.

Findings/conclusions: The sugarcane straw is a potential source of cellulose for the paper industry.

Key words: Agroindustrial sector, fiber length, pulp and paper industry, pulp mill effluents, sugarcane byproducts, XRD.

\section{INTRODUCTION}

The sugarcane straw is a residue that is generated during the sugarcane harvest and remains in the field (in the form of green leaves, dry leaves, tips and pieces of stem). These residues can be harnessed to improve the soil organic matter contributing to the 
sustainability of the system (Salgado et al., 2014). However, in the most of cases, the harvest residues are burned to prevent their re-integration into the crop system, affecting the recycling of soil nutrients. In some countries, the sugarcane straw from the mechanical harvesting is burned in coal-fired boilers to produce energy, feeding cattle, to produce cellulosic ethanol or to obtain paper (Ortiz et al., 2012).

In Mexico, there are 57 sugarcane mills being the Presidente BenitoJuarez $(\mathrm{PBJ})$ mill, the most important located in the tropical humid region of Tabasco, Mexico. This sugarcane mill has 20923 hectares under sugarcane cultivation in the Cárdenas and Huimanguillo municipalities. Their 4500 producers of sugar cane belong to two cane associations: CNC and CNPR (NUC, 2014). The sugarcane field has 29 cultivars, being the cultivars MEX 57-473, MEX-68P-23, CO-997, MEX-69-290 and SP-701284, which occupy 98\% of the cultivated area. In recent years, in light of the lack of cutters, and to improve the sustainability of the system, a green harvest system, which generates around $18 \mathrm{tha}^{-1}$ of sugarcane straw per harvest, was presented. The residue, considered waste in the Article 69 of the Sugar Cane Sustainable Development Law, has caused difficulties in cultivation work, generating accidental fires, and as a result, some farmers tend to incorporate them into the soil to take advantage of their positive effects on soil nutrient recycling and crop yield (Salgado et al., 2014).

Sugarcane straw is mainly composed of cellulose (32-44\%), hemicellulose (24-30\%), lignin (12-36\%) and ashes (2-7\%). This chemical composition may vary depending on the site of cultivation, climatic conditions, state of development of the cane, and the cane variety (Costa et al., 2015). On the other hand, cellulose has a wide use in the textile industry and in the paper manufacturing industry (Zhang et al., 2010). The lignocellulosic compounds from the sugarcane straw present a wide potential for use as textile fibers, raw material for paper manufacturing, or generation of biofuels or energy (Costa et al., 2015). Recently, several methods have been generated to modify the lignocellulosic components of the sugarcane straw, among them, are acetosolv (Saad et al., 2008), ethanol/water (Moriya et al., 2007), sodium hydroxide-soda/anthraquinone (AQ (Costa et al., 2013), and the biological usage of the fungus Ceriporiopsis subvermispora (Costa et al., 2015).

It is important to note that in Mexico, have been harvested 790481 hectares of sugarcane in the 2013/2014 cycle, from which $91.0 \%$ was burned for its harvest and only 9\% was harvested as green and incorporated into the crop system (NUC, 2014). It is evident that the sugarcane straw waste is not being used properly and it becomes urgent to show a potential use that would utilize lignocellulosic components of sugarcane straw, such as paper manufacture. Given these concerns, the aim of the present study is to evaluate the cellulose content and characteristics generated from sugarcane straw from five different sugarcane cultivars grown in the tropical humid region of Mexico.

\section{MATERIAL AND METHODS}

Straw samples. Samples of sugarcane straw from the cultivars MEX-69-290, MEX-68-P23, SP 70-1284, CO-997 and CP-72 2086 were harvested from November to February 2014 in sugarcane plantations of 12 months of age prior to harvest. These plantations were located in the towns C-31 and C-34 belonging to the supply area of the 
President Benito Juarez sugarcane mill in the Cárdenas municipality, Tabasco. These are located at $17^{\circ} 58^{\prime} 50^{\prime \prime} \mathrm{LN}$ and $93^{\circ} 27^{\prime} 28^{\prime}$ ' LO, at an altitude of 20 m.a.s.l. The average annual temperature is $26^{\circ} \mathrm{C}$; average rainfall is $2100 \mathrm{~mm}$, with a relative humidity of $80 \%$. Subsequently, thirty (30) stems of each sugarcane cultivar were randomly selected; the tips and dried leaves were collected and stored in large plastic bags. The sugarcane straw from each cultivar was milled through a $4 \mathrm{~mm}$ mesh in a forage chopper. Therefore, sub-samples of $3.0 \mathrm{~kg}$ have dried in a forced air oven at $65{ }^{\circ} \mathrm{C}$ for $48 \mathrm{~h}$. additionally; the subsamples were ground through a $2 \mathrm{~mm}$ mesh in a Wiley mill. The material was stored in plastic bags. The cellulose extraction was carried out using acid hydrolysis method according to Bolio et al. (2011). The method consisted of two phases as follows: Pretreatment with $\mathrm{NaOH}$ and Pulpeo through acid hydrolysis with $\mathrm{H}_{2} \mathrm{SO}_{4}$, finally, with cellulose whitened based on $\mathrm{NaClO}$.

Pretreatment. $800 \mathrm{~mL}$ of $10 \% \mathrm{NaOH}$ was mixed with $40 \mathrm{~g}$ of dried sugarcane straw. The mixture was heated to $70^{\circ} \mathrm{C}$ on a Thermo Scientific model CIMAREC heating plate until the first bubble was observed, then it was left boiling for $10 \mathrm{~min}$. After that time, the mixture was left for $20 \mathrm{~min}$ to have allowed a temperature decreasing, therefore, washed with tap water five times, and then with purified water until reaching a $\mathrm{pH}$ 7. The mixture was passed through a sieve to remove the liquid, and the residue was crumbled and placed into an aluminum tray for drying process in a forced air oven at $65^{\circ} \mathrm{C}$ for $12 \mathrm{~h}$. Finally, the dry weight of the cellulose fiber was recorded.

\section{The pulping process}

Hydrolysis. $230 \mathrm{~mL}$ of $0.4 \% \mathrm{H}_{2} \mathrm{SO}_{4}$ was added to $20 \mathrm{~g}$ of dried cellulose fiber and homogenized with a glass rod. The mixture was heated to $70^{\circ} \mathrm{C}$ on the heating plate. Once the mixture reached its boiling point, the vessel was capped for one hour. The mixture was left for $10 \mathrm{~min}$ to cool down and therefore, washed eight times with purified water with the aim to retain the residue.

Chlorination for lignin removal. The previously washed residue was placed into a beaker, and $285 \mathrm{~mL}$ of $3.5 \%$ sodium hypochlorite $\left(105 \mathrm{~mL}\right.$ of Chloralex ${ }^{\circledR}$ and $180 \mathrm{~mL}$ of purified water) was added. The mixture was placed in a boiling bath and have left to be heated for 10 min while being constantly stirred. Eight washes were then performed with purified water until had achieved a neutral $\mathrm{pH}$. The product was returned into the beaker.

Alkaline extraction. $200 \mathrm{~mL}$ of $20 \% \mathrm{NaOH}$ was added to the residue and stirred manually with the aid of a glass rod for $60 \mathrm{~min}$. Additionally, 12 washes with purified water were performed until had achieved a neutral $\mathrm{pH}$.

Bleaching. The cellulosic residue was placed into a $1000 \mathrm{~mL}$ beaker and $240 \mathrm{~mL}$ of $0.5 \%$ $\mathrm{NaClO}\left(15 \mathrm{~mL}\right.$ of Cloralex ${ }^{\circledR}$ with $270 \mathrm{~mL}$ of purified water) was added. This was manually homogenized with a glass rod for one hour. Thereafter, eight washes with purified water were performed. The white residue that appeared, which was the cellulose, was placed in flat-bottomed aluminum trays and left for $24 \mathrm{~h}$ at room temperature. Therefore, have allowed drying in a forced air oven at $65^{\circ} \mathrm{C}$ for $24 \mathrm{~h}$. Finally, the dry weight of the cellulose obtained was recorded and stored in plastic bags. 


\section{Studied variables}

Cellulose fiber and cellulose yield. The amount of cellulose fiber and cellulose extracted from the studied sample is $80 \mathrm{~g}$ of sugarcane straw, which was calculated using the Equation 1.

$$
\text { Yield of cellulose fiber or cellulose }(\%)=(C * 100) / 80 \mathrm{~g} \text { of dry straw Equation } 1
$$

Where: $C$ is the weight of cellulose fiber or cellulose extracted in each sample of sugarcane straw $(\mathrm{g})$.

Properties of cellulose. Length of the fiber $(\mu \mathrm{m})$. For the fiber length, had achieved a measurement of the cellulose samples, TAPPI 271 standard pulp and paper fiber of om-12, which was used while employing an automated optical microscope with polarized light in the range of $0.1 \mathrm{~mm}$ to $7.2 \mathrm{~mm}$. The Leica optical microscope used was the Model $\mathrm{DMRE}^{\mathrm{TM}}$, equipped with a DFC295 digital camera with lens at 2.5x and LAS Suite v4 software $^{\circledR}$. The studies were carried out in the Department of Wood, Cellulose and Paper (DMCP) at the Universidad de Guadalajara, Jalisco, Mexico.

Crystallinity and crystal size. Sugarcane straw and cellulose samples were extracted from the straw of five cultivars of sugar cane. Subsequently, samples were passed through a size 100 mesh screen.

To determine crystallinity and crystal size, $1 \mathrm{~g}$ of straw and cellulose extracted from the sugarcane straw was used. Readings were taken according to the X-ray Diffraction, Powders method (PXRD) technique; using a "Bruker D8 Advance Vantec" Diffractometer with $\mathrm{CuK}$ spectrum $(\alpha=1.5418 \AA$ and 35 of the $20 \mathrm{~mA}$ applied current), at the Academic Division of Basic Sciences Research Department, Universidad Autonoma de Juarez, Tabasco-Mexico. The percentage of crystallinity $\left(\mathrm{Xc}_{\mathrm{c}} \%\right)$, was calculated using the Equation 2.

$$
X c \%=100[1-(I 1 / I 2)] \quad \text { Equation } 2
$$

Where: $I 1$ is the minimum peak intensity; $I 2$ is the maximum intensity of the crystalline peak.

The crystal size was calculated using the Scherrer Equation (Equation 3).

$$
t=0.9 \lambda / B \cos \theta
$$

Equation 3

Where: $t$ is the crystal size; $\lambda$ is the wavelength of the utilized radiation $(\lambda \mathrm{Cu}) ; B$ is the width at the medium height of the sample at the diffraction peak; $\theta$ is the position of the diffraction peak; 0.9 is the crystal form factor.

Statistical analysis. For the studied variables: cellulose, cellulose yield, cellulose fiber and cellulose fiber yield, analysis of variance was performed with a completely randomized 
design, where the treatments were the sugarcane straw generated from five cultivars of sugarcane, which were analyzed with six replicates. To identify significant difference among treatments and statistical significance for all comparisons was made at $\mathrm{p}<0.05$. Tukey's multiple range test was used to compare the mean values of treatments using the SAS statistical software version $9.0^{\circledR}$. For the crystallinity and crystal size variables, only two readings of each sample were performed, therefore, the mean and the standard deviation were calculated as a measure of the error.

\section{RESULTS AND DISGUSSION}

Cellulose Fiber. According to the analysis of variance results, there are highly significant differences in the cellulose fiber after the extraction of the evaluated cultivars in terms of the sugarcane straw (Table 1). The CV was 3.9\%, which indicates a higher precision in the measurement of this parameter. According to the Tukey test, two groups of cultivars are observed in terms of the amount of the obtained cellulose fiber, with the cultivar MEX 69-290 being the smallest in comparison with the other cultivars, which is attributed to the fact that this cultivar lost more lignin and parenchymal material than the other evaluated sugarcane cultivars.

The other sugarcane cultivars were statistically the same, with values, which ranged from 31.4 to $32.8 \mathrm{~g}$ of cellulose fiber. In undertaking a sugarcane straw harvesting program to extract food-grade cellulose or cellulose fiber to create kraft paper, these sugarcane cultivars must be considered. Given these concerns, the yield of cellulose fiber also showed significant differences among the evaluated sugarcane cultivars (Table 1). The cultivar MEX 69-290 showed a significantly lower yield (35.1\%). The rest of the evaluated sugarcane cultivars did not differ significantly in the yield of cellulose fiber variable. The values ranged from $39.3 \%$ to $41.0 \%$, and coincided in the 39.5\% yield of cellulose fiber obtained from the cultivar Mex 79-431 (García et al., 2017).

Table 1. Cellulose fiber, yield of cellulose fiber, cellulose and cellulose yield of the sugarcane straw generated from five different sugarcane cultivars.

\begin{tabular}{l|c|c|c|c}
\multicolumn{1}{c|}{$\begin{array}{c}\text { Sugar cane } \\
\text { cultivars }\end{array}$} & $\begin{array}{c}\text { Cellulose fiber } \\
(\mathbf{g})\end{array}$ & $\begin{array}{c}\text { Fiber yield } \\
\text { of Cellulose }(\%)\end{array}$ & $\begin{array}{c}\text { Gellulose } \\
(\mathbf{g})\end{array}$ & $\begin{array}{c}\text { Cellulose yield } \\
(\%)\end{array}$ \\
\hline MEX 69-290 & $28.1 \mathrm{~b}^{\dagger}$ & $35.1 \mathrm{~b}$ & $8.4 \mathrm{~b}$ & $42.1 \mathrm{~b}$ \\
\hline CP-72-2086 & $31.4 \mathrm{a}$ & $39.3^{\mathrm{a}}$ & $9.1 \mathrm{a}$ & $45.5 \mathrm{a}$ \\
\hline MEX 68-P-23 & $32.2 \mathrm{a}$ & $40.3 \mathrm{ab}$ & $8.7 \mathrm{ab}$ & $43.5 \mathrm{ab}$ \\
\hline SP 70-1284 & $32.8 \mathrm{a}$ & $41.0 \mathrm{~b}$ & $8.5 \mathrm{~b}$ & $42.6 \mathrm{~b}$ \\
\hline CO-997 & $31.5 \mathrm{a}$ & $39.3^{\mathrm{a}}$ & $9.9 \mathrm{a}$ & $49.8 \mathrm{a}$ \\
\hline Mean $(\mathrm{g})$ & 31.2 & 39 & 8.9 & 44.7 \\
\hline GV $(\%)$ & 3.9 & 3.9 & 8.6 & 8.6 \\
\hline Prob. F of T. & $0.01^{* *}$ & $0.01^{* *}$ & $0.01^{* *}$ & $0.01 * *$ \\
\hline DMS & 2.1 & 2.6 & 1.3 & 6.6 \\
\hline
\end{tabular}

\footnotetext{
${ }^{\dagger}$ Averages with the same literal within the column are statistically equal to Tukey $(\mathrm{P} \leq 0.05)$.
}

** Highly significant 
Cellulose (g). The analysis of variance showed significant differences in the cellulose content of the sugarcane straw from the evaluated cultivars (Table 2). The CV was 8.6\%, which indicates a greater variation in the measurement of this parameter.

The Tukey test shows the cultivars MEX 69-290 and SP 70-1284, present the lowest cellulose content compared to the other studied sugar cane cultivars. The cultivars MEX 68-P23, CP 72-2086, and especially, the cultivar CO-997 contain more cellulose. With reference to the cellulose content, the yield of cellulose (\%), showed significant differences among the evaluated sugarcane cultivars (Tables 2, 3).

The cultivars with the lowest yield of cellulose were as follows: MEX 69-290 with 42.1\%, and SP 70-1284 with 42.6\%, respectively. The cellulose contents from the other evaluated cultivars were statistically equal with values that ranged from $43.5 \%$ to $49.8 \%$, where the cultivar CO-997 presented the highest yield (Figures 1, 2).

These yields are higher than reported by Costa et al. (2013), in cellulose obtained from sugarcane straw after an alkaline treatment using soda/AQ where the yield was $30 \%$.

Cellulose content. During cellulose extraction, it was observed that the cultivar MEX 68-P-23 consumed more sulfuric acid than the other samples and presented residues of precipitates in the alkaline extraction. This cultivar and the cultivar MEX 69-290 presented a viscous consistency, which made it difficult to separate the fibers.

The yield of cellulose generated from the cultivar CO-997 was similar to the 48\% reported for sugarcane bagasse (López et al., 2016: Sánchez-Muñoz et al., 2021). The results indicate that sugarcane straw could be a promising source of cellulose.

Crystallinity. The crystallinity of the cellulose is an indicative of the arrangement of the polymer chains in the cellulose fibrils. According to Candanedo, Roman \& Gray

Table 2. Crystallinity of cellulose from sugarcane straw and extracted cellulose from five different sugarcane cultivars.

\begin{tabular}{l|c|c}
\multicolumn{1}{c|}{ Cultivar } & $\begin{array}{c}\text { Cellulose crystallinity } \\
\text { of sugar cane straw }(\mathbf{\%})\end{array}$ & $\begin{array}{c}\text { Grystallinity of extracted } \\
\text { Cellulose } \mathbf{( \% )}\end{array}$ \\
\hline CO-997 & $38 \pm 0.5$ & $62 \pm 0.8$ \\
\hline CP 72-2086 & $36 \pm 0.7$ & $61 \pm 0.5$ \\
\hline MEX 68-P23 & $37 \pm 0.6$ & $69 \pm 0.9$ \\
\hline MEX 69-290 & $42 \pm 0.5$ & $62 \pm 0.8$ \\
\hline SP 70-1284 & $38 \pm 0.7$ & $77 \pm 0.8$ \\
\hline
\end{tabular}

Table 3. Size of cellulose crystal of untreated sugarcane straw and cellulose extracted from the straw of five different sugarcane cultivars.

\begin{tabular}{l|c|c}
\multicolumn{1}{c|}{ Cultivar } & $\begin{array}{c}\text { Size of straw crystal from } \\
\text { untreated cane }(\mathbf{n m})\end{array}$ & $\begin{array}{c}\text { Crystal size of } \\
\text { extracted cellulose }(\mathbf{n m})\end{array}$ \\
\hline CO-997 & $2.3 \pm 0.1$ & $2.2 \pm 0.05$ \\
\hline CP 72-2086 & $2.7 \pm 0.05$ & $2.2 \pm 0.1$ \\
\hline MEX 68-P23 & $2.6 \pm 0.1$ & $2.3 \pm 0.05$ \\
\hline MEX 69-290 & $2.5 \pm 0.1$ & $2.3 \pm 0.1$ \\
\hline SP 70-1284 & $2.6 \pm 0.5$ & $2.3 \pm 0.1$ \\
\hline
\end{tabular}



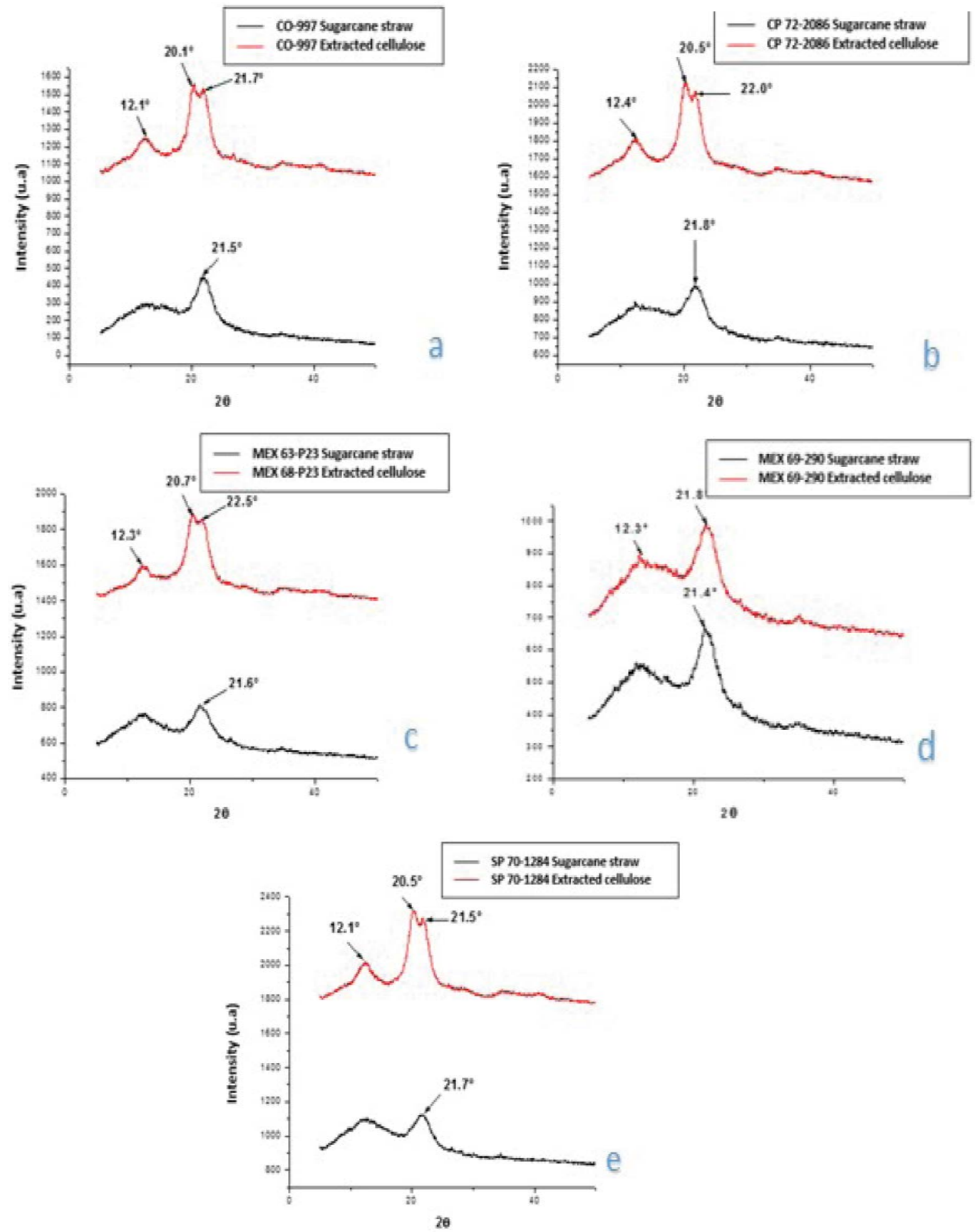

Figure 1. XRD patterns of untreated sugarcane straw and extracted cellulose from different sugarcane cultivars: a) CO-997, b) CP 72-2086, c) MEX 68-P23, d) SP 70-1284, and e) MEX 69-290.

(2005), if the fibrils are in disordered regions, they are amorphous, and if they are highly ordered, they are crystalline. In Figure 1, the diffractograms of the sugarcane straw sample and the extracted cellulose are presented.

The peak at $2=22.5^{\circ}$ and $2=12.3^{\circ}, 20.7^{\circ}$ and $21.6^{\circ}$ correspond to the cellulose structure (Wang et al., 2007; Costa et al., 2015). The crystallinity of the cellulose contained in the sugarcane straw was higher in the straw of the cultivar MEX 69-290. The rest of 


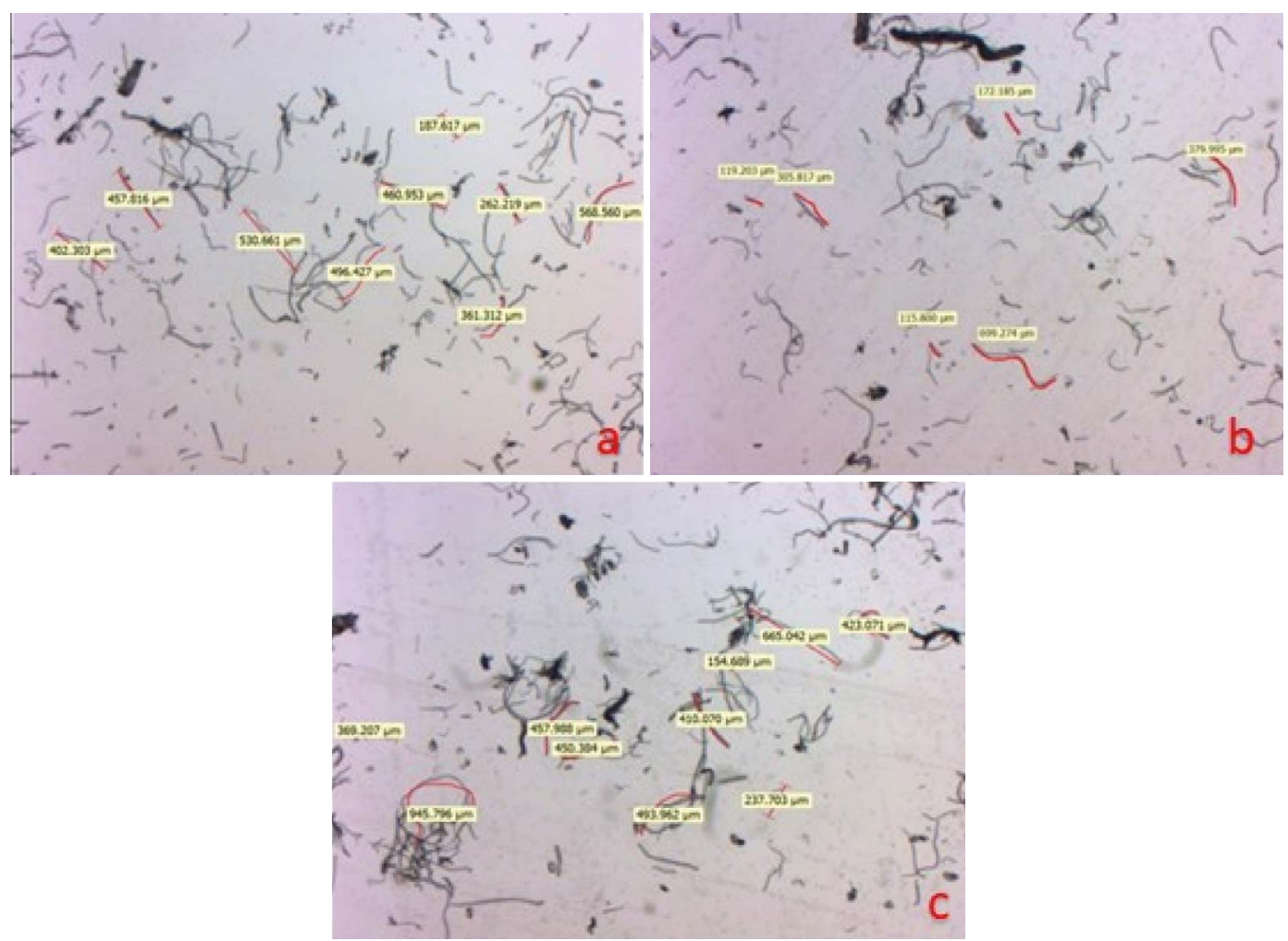

Figure 2. The fiber length of the studied sugarcane cultivars a) SP 70-1284, b) Mex 68-P23 and c) CP 72-2086, taken with an optical microscope, 25X amplification.

the studied sugarcane cultivars presented values similar to each other or below the average (Table 2). The average cellulose crystallinity of the sugarcane straw, 38.2\%, which was lower than the $56.07 \%$ crystallinity of the cellulose of the sugarcane straw (García et al., 2017). The crystallinity percentage of the extracted cellulose is higher in comparison to that observed in the cane straw cellulose (Table 2), which is due to the elimination of lignin and hemicellulose (Kumar et al., 2015). It was also observed an increasing in the crystallinity of the cellulose when passing from untreated sweet sugarcane bagasse to treated sugarcane bagasse. The peaks of the interferogram correspond to the links $\mathrm{O}-\mathrm{H}, \mathrm{H}-\mathrm{G}-\mathrm{H}, \mathrm{C}-\mathrm{H}$, and G-O-C of the cellulose molecules (Visakh \& Thomas, 2010), which coincides with that reported by García et al. (2017), when analyzing the purity of the cellulose extracted from the sugarcane cultivar Mex 79-431, extracted with both methods.

The crystallinity of the cellulose extracted from the sugarcane straw was higher for the cultivar SP 70-1284 with 77\%, followed by the cultivar MEX 68-P23 with 69\%, and the other studied cultivars presented a cellulose crystallinity content ranged from 61 to $62 \%$ (Table 2).

The crystallinity of sugarcane straw cellulose is similar to the cellulose extracted from cotton, flax and ramie, which have a crystalline fraction ranged from 60 to $70 \%$ and higher than the 55\% crystallinity determined for sugarcane bagasse cellulose (López et al., 2016). The crystallinity of the cultivar SP-70-1284 was similar to the crystallinity of the cultivar Mex 79-431 (74\%) reported by García et al. (2017). 
The average size of the cellulose crystals of the untreated sugarcane straw in the studied cultivars was $2.6 \mathrm{~nm}$ (Table 3). This crystal size was similar to those reported for the Asplenium fernandezianum Kunze. (2.6 nm) (Newman, 1999), and for sugarcane bagasse (López et al., 2016), and lower than those reported for the rachis of the banana cluster (4.46 $\mathrm{nm}$ ) (Bolio et al., 2011). The crystal size in the cellulose extracted from the sugarcane straw of the evaluated cultivars was similar with an average of $2.3 \mathrm{~nm}$ (Table 3); in comparison to the crystal size reported for the cellulose extracted from the sugarcane straw of the cultivar MEX 79-431 (García et al., 2017), which generated greater crystallinity by losing the amorphous area and better defining the arrangement of cellulose molecules.

Fiber length. The results obtained with the sugarcane cultivars SP 70-1284, MEX 68P23, and CP 72-2086, showed that the size of the cellulose fiber extracted is small (Figure 2 ), which prevents the formation of kraft paper sheets. An increased order in the size of the fiber was reported in Figure 2 as follows: SP 70-1284 (568.5-187.6 $\mu \mathrm{m})<$ MEX 68P23 (699.2-115.8 $\mu \mathrm{m})<$ CP 72-2086 (945.7-154.6 $\mu \mathrm{m})$. The fiber length of the sugarcane cultivar CP 72-2086 is equal to the average length of the eucalyptus (Eucalyptus occidentalis Endl.) fiber with $940 \mu \mathrm{m}$, and less than maize (Zea mays L.) leaf $(1860 \mu \mathrm{m})$, of sugarcane bagasse $(1500 \mu \mathrm{m})$, and henequen "pineapple" (Ananas comosus (L.) Merr.) fibers (1700 $\mu \mathrm{m})$ (Prado, Anzaldo, Becerra, Palacios, Vargas \& Rentería, 2012). The small size of the cellulose fiber of the evaluated sugarcane cultivars is due to the initial sugarcane straw size used to extract the cellulose, which was $2 \mathrm{~mm}$ (the particle size after the straw milling process). This indicates that in a near future studies, the particle size would had achieved an increasing, which would range from 30 to $40 \mathrm{~mm}$ (Costa et al., 2013).

\section{CONGLUSIONS}

The studied sugarcane cultivars showed significant differences in the cellulose content obtained from the straw. The highest content and yield of cellulose was obtained by treating the straw of the cultivar CO-997 and the lowest in the cultivars MEX 69-290 and SP-701284. The crystallinity of the cellulose extracted from treated sugarcane straw was higher in comparison to that observed in the cellulose of the untreated straw, which is due to the effect of treatment with acid hydrolysis. Among the different studied sugarcane cultivars, SP 70-1284 and MEX 68-P23 presented the highest crystallinity of the cellulose in treated straw. The crystal size of the cellulose in the untreated sugarcane straw presented an average of $2.6 \mathrm{~nm}$, being larger, to the crystal size of the cellulose extracted from the treated sugarcane straw $(2.3 \mathrm{~nm})$. The length of the cellulose fibers extracted from the treated sugarcane straw was less than $1000 \mu \mathrm{m}$ and presented wide ranges of variation within each cultivar. The sugarcane straw cellulose from the studied cultivars has similar characteristics and presents potential for use in various areas, in the paper and fabric industry, as well as in composite materials, biomaterials, etc.

\section{ACKNOWLEDGMENTS}

To MASCAÑA research group of the Colegio de Postgraduados Tabasco Campus for the financial support and the facilities to carry out the present study in the Central Laboratory of the Colegio de Postgraduados Tabasco campus, Mexico. 


\section{REFERENGES}

Bolio-López, G.I., Valadez, G.A., Veleva, L., \& Andreeva, A. (2011). Whiskers de celulosa a partir de residuos agroindustriales de banano: obtención y caracterización. Rev Mex Ing Quim, 10(2), 291-299. http:// www.scielo.org.mx/pdf/rmiq/v10n2/v10n2a13.pdf.

Candanedo, M.B., Roman, M., \& Gray, D.G. (2005). Effect of reaction conditions in the properties and behavior of wood cellulose nanocrystal suspensions. Biomacromolecules, 6(2), 1048-1054. http://dx.doi. org/10.1021/bm049300p

Costa, S.M., Aguiar, A., Luz, S.M., Pessoa, A., \& Costa, S.A. (2015). Sugarcane Straw and its cellulosic fraction as raw materials for obtainment of textile fibers and other bioproducts. In: Kishan Gopal Ramawat, Jean-Michel Mérillon (Eds.), Polysaccharides, 1-17. https://doi.org/10.1007/978-3-319-03751-6_53-1

Costa, S.M., Mazzola, P.G., Silva, J.G.A.R., Pahl, R., Pessoa, A.Jr., \& Costa, S.A. (2013). Use of sugar cane straw as a source of cellulose for textile fiber production. Ind Crop Prod, 42(1), 189-194. https://doi. org/10.1016/j.indcrop.2012.05.028

García-Estrada, Y., Salgado-García, S., Bolio-López, G.I., Córdova-Sánchez, S., Lagunes-Espinoza, L.C., Falconi-Calderón, R., \& Veleva, L. (2017). Métodos para extraer celulosa de la paja de caña de azúcar (Saccharum spp.). Agroproductivity, 10(11), 54-59. http://revista-agroproductividad.org/index.php/ agroproductividad/article/view/65/60.

Kumar, G.C., Kumar, P.M., Gupta, S., Sinder, S. M., Rao, M.K.V., Jagadeesh, B., Swapna, V., \& Kamal, A. (2015). Isolation and characterization of cellulose from sweet sorghum bagasse. Sugar Technology, 17(4), 395-403. https://doi.org/10.1007/s12355-014-0339-9

López-Martínez, A., Bolio-López, G.I., Veleva, L., Solórzano-Valencia, M., Acosta-Tejada, G., HernándezVillegas, M.M., Salgado-García, S., \& Córdova-Sánchez, S. (2016). Production of cellulose from bagasse (Saccharum spp.). Agroproductivity, 9(7), 41-45. http://revista-agroproductividad.org/index.php/ agroproductividad/issue/view/39/Vol.\%209\%20N\%C3\%BAm.\%207.

Moriya, R.Y., Gonçalves A.R., \& Duarte M.C. (2007). Ethanol/water pulps from sugar cane straw and their biobleaching with xylanase from Bacillus pumilus. Appl Biochem Biotech, 137(1-12), 501-513. https://doi. org/10.1007/s12010-007-9075-x

NUC- National Union of Cañeros. (2014). Statistics of the Agroindustria of the Sugar Cane, NUC. http:// www.caneros.org.mx/site_caneros/estadisticas/nacional.pdf.

Newman, R.H. (1999). Estimation of the lateral dimensions of cellulose crystallites using NMR signal strengths. Solid State Nucl Magn Reson, 15(1), 21-29. https://doi.org/10.1016/S0926-2040(99)00043-0

Ortiz, L.H., Salgado, G.S., Castelán, E.M., \& Córdova, S.S. (2012). Perspectivas de la cosecha de la caña de azúcar cruda en México. Rev Mex Cienc Agríc, 3(sp4), 767-773. http://www.scielo.org.mx/pdf/remexca/ v3nspe4/v3nspe4a20.pdf.

Prado-Martínez, M., J. Anzaldo-Hernández, B. Becerra-Aguilar, H. Palacios-Juárez, J.J. Vargas-Radillo., \& Rentería-Urquiza, M. (2012). Caracterización de hojas de mazorca de maíz y de bagazo de caña para la elaboración de una pulpa celulósica mixta. Madera Bosques, 18(3), 37-51. http://www.scielo.org.mx/ pdf/mb/v18n3/v18n3a4.pdf.

Saad, M.B.W., Oliveira, M.L.R., Cândido, G.R., Quintana, G., Rocha, M.J.G., \& Gonçalves, R.A. (2008). Preliminary studies on fungal treatment of sugarcane straw for organosolv pulping. Enzyme Microb Tech, 43(2), 220-225. https://doi.org/10.1016/j.enzmictec.2008.03.006

Salgado, G.S., Aranda, I.E.M., Castelán, E.M., Ortiz, L.H., Palma, L.D.J., \& Córdova, S.S. (2014). Qué hacer con la paja de la cosecha mecanizada de la caña de azúcar. Agroproductividad, 7(2), 5-10. http://revistaagroproductividad.org/index.php/agroproductividad/issue/view/21/Vol.\%207\%20N\%C3\%BAm.\%202.

Sánchez-Muñoz, S., Mier-Alba, E., da Silva, S.S., \& A. K. Chandel. (2021). Commercial Washing DetergentsAssisted Alkaline Pretreatment for Lignocellulosic Sugars Production: A First Report. Sugar Tech. https://doi.org/10.1007/s12355-021-00988-2

Visakh, P.M., \& Thomas, S. (2010). Preparation of Bionanomaterials and their Polymer Nanocomposites from Waste and Biomass. Waste Biomass Value, 1(1), 121-134. https://doi.org/10.1007/s12649-010-9009-7

Wang, B., Sain, M., \& Oskman, K. (2007). Study of structural morphology of hemp fiber from the micro to the nanoscale. Appl Compos Mater, 14, 89-103. https://doi.org/10.1007/s10443-006-9032-9

Zhang, X.Y., Duan, T.C., Zhao, N., Xiao, H., Shi, W.M., \& Zhang, L.X. (2010). Facile fabrication of largescale microtubes with a natural template-kapok fiber. Chinese J Polym Sci, 28(5), 841-847. https://doi. org/10.1007/s10118-010-0044-4 